COGNitive Studies | Études COGNitives, 11 SOW Publishing House, Warsaw 2011

\author{
ANNA KISIEL \\ (ania-kisiel@tlen.pl)

\section{HOW TO ANALYZE CONTEXTUALITY OF METATEXTUAL LANGUAGE UNITS? NOTES ON THE RELATION: TRS - PARTICLE SEMANTICS}

\begin{abstract}
The presented article is devoted to further (after Kisiel 2010 [in press]) discussion about contextuality of metatextual language units, especially particles. Having selected contextual particles as an example, the author shows how specific structuralisation of TRS is strictly connected with particle meaning. The observation leads to the conclusion that examination of TRS cannot be avoided when analysing particles. Untangling particles meaning has to be based on describing the TRS they work on. Such a procedure has been only recently applied to Polish lexicography. Keywords: metatext, contextuality, particles, thematic-rhematic structure, lexicography.
\end{abstract}

Contextuality $^{1}$ of particles has not been so far a matter of a detailed and systematic analysis. In my previous paper (Kisiel 2010 [in press]), while discussing the contextuality of such language units as tylko 'only', te z 'also' and wręcz 'simply', I pointed out how erroneous - and confusing - certain views on contextual requirements of a metatext can be. Using the example of the three aforementioned particles I demonstrated how recognizing a particle as contextual can, without basing on language material, lead to entering wrong semantic data into a language unit explication formula. What I was trying to prove was that often false assumptions on a particle as being contextual result in mixing its semantics with a role that is enabled by its meaning.

The presented article is devoted to further, particular problems. It presents selected contextual particles belonging to different subgroups of the class: notabene 'nota bene', natomiast 'while, however', co więcej 'what's more', tym bardziej 'all the more' and $w$ szczególności 'in particular'. By comparing the structuralisation

\footnotetext{
${ }^{1}$ Understood as language unit's requirement of a directly preceding text having its own TRS, which is somehow connected with elements of TRS introduced by the language unit. Generally speaking, the connection consists in coforming the two subordinate structures into one TRS in a frame of superordinate theme. (For details see Kisiel 2010 in press.)
} 
of sentences with these particles, the main thesis on examining the TRS (thematicrhematic structure) as a necessary procedure in explicating metatextual language units will be strengthened. It will be, precisely speaking, proved that without taking the TRS into careful consideration it is not possible to present real, rather than fortuitous, contextual expectancies of particles and, as a result, it is not possible to responsibly compare particular entities of the class.

\section{Notabene 'nota bene' and the problem of the incompletely fixed TRS $_{1}-$ TRS $_{2}$ relation}

Notabene 'nota bene' is commonly seen as a language unit introducing additional, so called supporting information (without specifying what the supporting role is exactly about), or even as able to introduce what is „,not directly connected with the preceding fragment, and then to go back to the main line of thought without mishap" (Walusiak 1999:31) ${ }^{2}$. Although introducing a dictum that is not bound with what has just been said is etymologically the core of notabene "nota bene' function, giving a piece of information in no way connected with what is being said is, pragmatically, dubious. Also the language material accrued in the Polish language national corpus does not confirm the thesis on otherness of what is commented by notabene 'nota bene' and a cotext (understood as the directly preceding text). Given in a sequence of sentences that does not seem to be linked, such as

(1) Kasia przyjdzie na obiad. Notabene pada deszcz. 'Kate is coming to dinner. Nota bene it's raining.',

the interlocutor will concentrate on searching for some kind of connection between the received pieces of information, in this case: Kate's visit and the weather. Looking for the common ground for what we hear has been described in the Gricean Maxim of Relation. It is not without a reason to suspect that ascribing nonconnectedness to what is commented by notabene 'nota bene' is a result of not looking thoroughly enough into the TRS of a cotext and a notabene-sentence.

If we look into the definitions given by contemporary Polish language dictionaries ('słowem notabene poprzedzamy nawiasową informację, którą wplatamy w tekst lub dodajemy do tekstu i na którą chcemy zwrócić uwagę słuchacza' 'the word notabene is used to precede parenthetical information, included in a text or added to it, which we want to direct someone's attention to' (ISJP), 'wyrażenie zwracające uwagę, podkreślające jakąś część tekstu albo wypowiedzi' 'an expression pointing out or emphasizing a part of a text or statement' (SWJP), 'wyraz wtrącony w treść zdania dla podkreślenia jakiejś jego części' 'a word put in the content of a sentence to emphasize a part of it' (SJPDor)), we will notice that the information on which notabene 'nota bene' comments is seen as parenthetical, added, weaved and, at the same time, as emphasized, dragging attention to something being said. As for the parenthetical feature of a notabene-sentence, it can be questioned by the

\footnotetext{
${ }^{2}$,wprowadzić informację niezwiązaną bezpośrednio z poprzedzającym fragmentem, a potem bez przeszkód wrócić do głównego toku swojej myśli"
} 
observation of post-conjunction usages of notabene 'nota bene'. It can, interestingly enough, be used after and, a language unit that assumes equivalence of linked information, see

(2) Kasia przyjdzie na obiad i, notabene, nie będzie sama. 'Kate is coming to dinner and nota bene she won't come alone.'

Besides, while describing a piece of information commented by notabene 'nota bene' as parenthetical lexicographers made a common mistake consisting of inscribing the particle's meaning into a rhema that is commented by the particle. In other words, it is not the information that is parenthetical but it is nothing else than notabene 'nota bene' that makes us see the information as such (for more details on common errors in defining a metatext see Grochowski, Kisiel, Żabowska 2009).

According to what has been said in the preliminary part of the presented text, it is necessary to look into the TRS of notabene-sentences in order to, even if only tentatively, describe its function. There are five utterances of the same cotext TRS but of a different structure, and position, of notabene 'nota bene' and the part commented by notabene 'nota bene':

$\mathrm{T}_{1}-$ Ala $-\mathrm{Q}_{1}$ co ma 'what she has' $\mathrm{R}_{1}$ - kota 'a cat'

(3) Ala ma kota, notabene strasznie leniwego. 'Ala has a cat, nota bene an awfully lazy one.'

$\mathrm{T}_{2}$ kot, którego ma Ala 'a cat that Ala has' $\mathrm{Q}_{2}$ jaki jest 'what it is like' $\mathrm{R}_{2}$ strasznie leniwy 'awfully lazy'

(4) Ala ma kota - notabene to daje jej dużo radości. 'Ala has a cat — nota bene it gives her a lot of pleasure.'

$\mathrm{T}_{2}$ Ala — to, że ma kota 'Ala — that she has a cat' $\mathrm{Q}_{2}$ jak się wobec tego czuje 'how she feels about it' $R_{2}$ daje jej dużo radości 'it gives her a lot of pleasure'

(5) Ala ma kota, co mnie notabene strasznie dziwi. 'Ala has a cat, which surprises me a lot.'

$\mathrm{T}_{2}$ ja — to, że Ala ma kota 'me - that Ala has a cat' $\mathrm{Q}_{2}$ co wobec tego czuję 'how I fell about it' $\mathrm{R}_{2}$ dziwi mnie to 'it surprises me'

(6) Ala, notabene durna dziewucha, ma kota. 'Ala, nota bene a stupid girl, has a cat.'

\footnotetext{
${ }^{3}$ In the notations, $\mathrm{T}_{1}$ stands for a thematic part of a cotext, $\mathrm{Q}_{1}-$ for a thematic aspect given in a cotext, $R_{1}$ - for a rhematic part of a cotext. The analogical markers with symbol 2 stand for the identical part of a sentence in a part commented by notabene 'nota bene'.
} 
$\mathrm{T}_{2}$ Ala $\mathrm{Q}_{2}$ jaka jest 'what she's like' $\mathrm{R}_{2}$ durna dziewucha 'stupid girl'

(7) Ala ma kota. Notabene to durna dziewucha. 'Ala has a cat. Nota bene it's a stupid girl.'

$\mathrm{T}_{2}$ Ala $\mathrm{Q}_{2}$ jaka jest 'what she's like' $\mathrm{R}_{2}$ durna dziewucha 'stupid girl'

(8) Ala ma kota. Notabene rodzice wciąż muszą się nim zajmować. 'Ala has a cat. Nota bene her parents have to take care of it all the time.'

$\mathrm{T}_{2}$ rodzice 'parents' $\mathrm{Q}_{2}$ jakie mają obowiązki wobec kota Ali 'what responsibilities they have towards Ala's cat' $R_{2}$ wciąż muszą się nim zajmować 'have to take care of it all the time'

The short review of notabene-sentence structuralizations given above is already enough to show that the relation between the TRS on which notabene 'nota bene' works and the TRS of a cotext is not constant. (3) shows the simplest possibility of notabene-sentence structuralizing - with themastization of a cotext's rhema in $\mathrm{TRS}_{2}$. It is not a very different case in (8), an utterance with a new thema in the second sentence, keeping however what is said in $R_{1}$ within the thematic part ${ }_{2}$. Utterances (4)-(5) are, on the other hand, more complex as their structure consists of a so-called notional thema. Utterances of the kind have not been so far described accurately enough, therefore the entanglement of TRS proposed here can be treated only as a hypothesis. What can be observed regardless of the understanding of such a thema is that within a thematic part ${ }_{2}$ there is, again, $\mathrm{R}_{1}{ }^{4}$. Yet, it is necessary to say that as regular as the aforementioned situation is adding something new about the subject given in a cotext in notabene sentences (see (6), (7)) and in such a situation the only shared feature of both rhemas $\left(R_{1}\right.$ and $\left.R_{2}\right)$ is being known about the same object. It is not before notabene 'nota bene' is added as a comment to one of them that some kind of a relation of content between rhemas is looked for. Since it is precisely notabene 'nota bene' that appoints the relation between what has been said (or is being said like in parenthetical (6)) and what takes ,syntactic" place next to notabene 'nota bene'. The nature of the relation is motivated by the etymological meaning of notabene 'nota bene' 'notice well', ie. a speaker drags the interlocutor's attention to a certain fact under which the formerly given information appears to take a new dimension. The described mechanism can be roughly presented as 'I would like you to notice that $R_{2}$ is true about $T_{2}$ because then you will know what to think about what I said earlier'. Let's observe it using the following example:

(9) Ala przyszła na spotkanie ze swoim chłopakiem, notabene blondynem. 'Ala came to the meeting with her new boyfriend, nota bene a blond guy.'

The speaker here wants his or her interlocutor to notice that Ala's boyfriend is blond. Why? The reason is known to the interlocutor thanks to the shared

\footnotetext{
${ }^{4}$ Similarly, in an utterance with extremely interesting TRS Ala ma kota. notabene wszyscy wiedza, że to Jan o niego dba. 'Ala has a cat. Nota bene everyone knows it is Jan who takes care of it.', where $\mathrm{T}_{2}$ consist in common knowledge on the subject, the knowledge concerning what has been before given as rhematic.
} 
epistemic world. In the presented case it can be because Ala has never liked fairhaired boys. Or because once a psychic has told her that she is going to marry a blond man. Or because the speaker had bet his interlocutor that Ala's next boyfriend was going to be blond. The motivation is of no significance here. What is essential though is that the description of Ala's boyfriend influences the reading of what has been said. Without the description the interlocutor might not estimate correctly the value of what has been said. (See also that splitting $\mathrm{TRS}_{1}$ in type (6) utterances in such a way that part of the structure is given after $\mathrm{TRS}_{2}$ does not in any sense mean that $\mathrm{TRS}_{1}$ is epistemicly later than $\mathrm{TRS}_{2}$; linearization here does not follow the structure of presented knowledge.)

This is why notabene 'nota bene' can be collated with swoja droga 'anyway', nawiasem mówiac 'incidentally' and zreszta 'besides, actually', which function in TRS in an analogical way, whereas it should not be compared with particles like zaś 'while', natomiast 'while, however' as what they comment is bonded with a cotext in a regular way. At the same time, it is obvious, when looking at these examples, that the role of a particle meaning in deciding on a type of connection between a cotext and what is commented on by a particle cannot be overestimated. It is not without a reason that the structuralization of sentences with natomiast 'while, however' is closer to the one of a te $\dot{z}$-sentence than to the one of a notabene-sentence, see

(10) Ala ma kota, Jurek natomiast — psa. 'Ala has a cat, while Jurek has a dog.'

(11) Ala ma kota, psów natomiast nienawidzi. 'Ala has a cat, while dogs she cannot stand.'

In utterances with natomiast 'while, however' the speaker speaks about a new object in the same respect as he or she has already spoken about another object (or, similarly, he or she speaks about the same object in the reverse respect compared to what he has said earlier, see (11) or Ala ma kota. Nie ma natomiast przyjaciót. 'Ala has a cat. But what she doesn't have are friends.'). To put it in other words, natomiast 'while, however' is used to compare two rhematic objects (and this is the feature that creates a similarity between the particle and te $\dot{z}$ 'also'), to point out a parallelism of the functioning of both objects (a dog and a cat in (10) as having owners (not identical) or in (11) as arousing some kind of feelings (not identical, opposing) in a particular person). Unlike te $\dot{z}$ 'also', natomiast 'while, however' assumes talking about two objects, opposing in a way, while tez 'also' can be used also in a situation when the other object is referred to as an object known to the interlocutor based on the shared knowledge.

It is worth noticing that it is the way natomiast 'while, however', notabene 'nota bene' and cognate units function in TRS which makes their grammar qualification controversial. As they work on compound TRS, there is a temptation to equate the nature of the bond between a cotext and a particle-sentence with conjunctionness (as a conjunction is understood in Wajszczuk 1997). In order to seriously consider the problem, i.e. to discuss the thesis of their not having a conjunction affiliation, it would be necessary to scrupulously examine and present the possible structures of sentences with the above-mentioned particles. Such a detailed analysis is not 
possible in a short and preliminary article as this one here. The aim of the presented text is only to point out that an unambiguous description of a metatext is not possible without further development of the methods of grammatical qualification based on the role of a language unit in TRS.

\section{Tym bardziej 'all the more', co więcej 'what's more' and the expec- tations on filling up TRS}

Using the example of notabene 'nota bene' and natomiast 'while, however' we have shown that langugae units of different contextual expectances (in other words, working on differently structuralized TRSes) should be described separately as structural otherness always suggests semantic otherness. The next paragraph presents language units working on identical, always the same, TRS (i.e., where a cotext and a commented part are always bound in the same way). Co więcej 'what's more", tym bardziej 'all the more' i w szczególności 'in particular' have been chosen here to show that even when the structure is the same, particular links (and especially their nature) between its parts can be different.

The chosen language units are considered in Polish lexicography to be semantically related. Most often the relation is indicated indirectly, see defining tym bardziej 'all the more' with zwłaszcza 'especially' that is, in turn, seen as synonymous with $w$ szczególności 'in particular' (USJP, PSWP) or recognizing tym bardziej 'all the more' and co więcej 'what's more' as synonyms definiendum co dopiero 1 'let alone' (PSWP) or choosing mało tego 'not only', having tym bardziej 'all the more' as its antonym, as a synonym of co więcej 'what's more' (ISJP). Even these examples alone show that the language units in question are used in lexicography to formulate hypotheses that are not proven and, as it can be assumed, are proposed on the spot.

The most surprising of the aforementioned decisions is the one about treating tym bardziej 'all the more' and co więcej 'what's more' as equal definienses of another language unit. Even at the very first glance these particles seem to be so different that they should not be used together within one semantic hypothesis. The first one, as it has been untangled in ISJP, establishes the truth relation between two states of things, in other words, expresses a conviction about the existence of a dependence between saying something about an object $\mathrm{A}$ and saying something else about an object $\mathrm{B}$; while the latter is used to add new information on a formerly

\footnotetext{
5 It seems that the expression has gained the status of a language unit. A fundamental argument for such a decision is the fact that the elements co and wieccej do not participate in proportional relations with other language elements within the meaning. It is indeed true that the lack of exchangeability between więcej and mniej is due to the origin of co wiecej - a language unit clearly connected with speaking (see powiem więcej 'I'll say more' vs ' powiem mniej 'I'll say less'). Separate consideration should be devoted to the series co gorsze, co dziwne, co ciekawe, the elements of which - despite the irregularities such as co gorsza vs co gorsze, that are possible to explain within a language system — seem to be realizations of one language unit: co _ with a position open to a comparative or superlative form of an adjective. Such a language unit should be treated as a metatextual abridgment of powiem coś, co jest_ 'I'll say something that is _.'. It is true that some expressions of the kind are more common, see, for example, co ciekawsze 'what's more interesting' and co fajniejsze 'what's cooler', but so far there are no reasons to consider the difference to be of a different nature that the one related to frequency.
} 
given thema. Both, however, set a dependence between two rhemas and it is, as a result, true for both that the commented rhema has to be assigned to the same superordinate thema as the previous rhema, see ${ }^{6}$

(12) ${ }^{7}$ Pomogła 'im, tym bardziej 'nam pomoże. / Pomogła im, co więcej i nam pomoże. 'She has helped them, all the more she's going to help us.' / 'She has helped them, what's more she's going to help us' ( $\mathrm{T}_{0}$ ona 'she' $\mathrm{Q}$ komu pomaga 'whom she has helped')

(13) Pomogła im 'ona, tym bardziej / co więcej pomogą im też 'inni. 'It was her who has helped them, all the more / what's more others are going to help us too.' ( $\mathrm{T}_{0}$ oni 'they' Q kto im pomaga 'who has helped them')

(14) Nie mam żad'nego 'kota, tym bardziej ta'kiego, co by ci 'sikał pod 'drzwiami. 'I don't have a cat, all the more I don't have the one peeing at your doors.' ( $\mathrm{T}_{0}$ ja 'me' Q czego nie mam (wiesz, o czym będę mówić) 'what I don't have (you know what I'm going to talk about)')

(15) To nie było bezpod'stawne, tym bardziej / co więcej (nie było) krzyw'dzące. 'It was not groundless, all the more / what's more it wasn't unfair.' ( $\mathrm{T}_{0}$ to 'it' Q jakie nie było 'what it wasn't like')

(16) 'Karol oblał egzamin, tym bardziej / co więcej 'Jan go obleje. 'Karol has failed the exam, all the more / what's more Jan is going to fail it, too.' ( $\mathrm{T}_{0}$ egzamin 'the exam' $Q$ jaka jest jego zdawalność 'what its passing rate is')

It can be said that the base structure is the same in all cases. The same can be also said about all the contextual particles if we decide to see the class as consisting of language units being commentaries assigned to a rhema. It becomes clear, therefore, that the entanglement of TRS elements' arrangement is not enough. As it has already been said, to describe the meaning of a particle (and, at the same time, its role in TRS) one has to determine the possibilities of filling up TRS with language elements and the relations between them. Only by carrying out this procedure for all particles we might think about segregating the elements of the class into smaller groups consisting of units that are close in meaning.

What appears to be helpful while conducting the procedure is inscribing utterances with contextual particles within the frames set by the highest metapredicates, i.e. conjunctions, see

(17) Skoro / Jeżeli on nie zdał, to tym bardziej ja nie zdam. 'If he hasn't passed it, then all the more I won't pass.'

(18) Ona się zgodziła, więc tym bardziej dyrektor się zgodzi. 'She has agreed on that, so all the more the director will.'

\footnotetext{
${ }^{6}$ According to the following examples it is structural constancy that is taken into consideration while interchanging tym bardziej 'all the more' and co więcej 'what's more'; for the moment semantic changes are not taken into account (see below).

${ }^{7}$ Here and in the examples below' marks sentence stress.
} 
(19) Nie tylko jest córką gubernatora, ale co więcej ma wielu wpływowych przyjaciól. 'Not only is she a governor's daughter, but what's more she has a lot of influential friends.'

(20) Jest piękna, bystra i co więcej diabelnie utalentowana. 'She's beautiful, smart and what's more awfully talented.'

The naturalness of these kinds of sentences, together with the fact that the interchange between tym bardziej 'all the more' and co wieccej 'what's more' would upset this naturalness, gives the base for predicting the difference in meaning of the two particles. Observing the placement of other particles in sentences with tym bardziej 'all the more' and co więcej 'what's more' gives a similar effect, see for example

(21) Nie je mięsa, podrobów, serów, co więcej nie pije nawet mleka. 'She doesn't eat meat, offal and cheese, what's more she doesn't even drink milk.'

(22) 'Nie je nawet mięsa, co więcej nie pije mleka. 'She doesn't even eat meat, what's more she doesn't drink milk.'

(23) Nie pije nawet mleka, tym bardziej nie je mięsa. 'She doesn't even drink milk, all the more she eats no meat.'

(24) *Nie pije mleka, tym bardziej nie je nawet mięsa. 'She doesn't drink milk, all the more she doesn't even eat meat.'

If we assume, provisionally, that co więcej 'what's more' adds new information that is not implied by the previous dictum, i.e. the information on the sayable being true also about another object, and therefore gives the impression of leading all of what is being said to some kind of extreme (that is registered in dictionaries by 'not only..., but also...'), then the use of nawet 'even' by the rhema commented by co więcej 'what's more' is clear. Namely, nawet 'even' points out here that a speaker has not thought that what he is saying can be lead to the extreme (that turns out to be possible exactly because of the possibility of ascribing the given dictum as true to another object). On the other hand, it is unclear when nawet 'even' is used in a cotext as the cotext says nothing about the possibility of pondering on the extreme version of the situation in question. If we assume then, that tym bardziej 'all the more' informs that the speaker makes sure of the truth of what he or she is saying about a particular object, based on what he or she has truly said about another object (in a cotext), it is clear why nawet 'even' is used in a cotext, but not ascribed to a rhema commented by tym bardziej 'all the more'. Nawet 'even' used in a cotext points to the fact that the truthfulness of the first dictum comes as a surprise. The second part of the sentence, the part including tym bardziej 'all the more', can bring no surprise as its truthfulness is based on what has been said earlier - and therefore it does not allow nawet 'even'. It is possible that this kind of sentences was a base for ISJP to suggest the antonymous character of the two particles in question (tym bardziej 'all the more' and co więcej 'what's more'). However, such a hypothesis cannot be supported here. 
Co więcej 'what's more' adds certain information (on a given object), tym bardziej 'all the more' derives one piece of information from another (within the framework of speaking about the same object) - this is why co więcej 'what's more' cannot be used in a sentence (14), where the information on a cat is presented as more and more detailed. The obstacle there is due to the fact that by using co więcej 'what's more' the speaker would suggest that he or she has neither a cat nor a cat peeing at the interlocutor's door, which results in giving obviously redundant information. Such a differentiation between the two particles can also explain why tym bardziej 'all the more' cannot substitute co więcej 'what's more' in

(25) Karol nie zdał egzaminu, co więcej złamał nogę po drodze do domu. 'Karol didn't pass the egzam, what's more he broke his leg on his way home.'

(26) Karol nie zdał egzaminu, co więcej Jana wyrzucili z uczelni. 'Karol didn't pass the egzam, what's more Jan has been expelled from university.'

Moreover, it explains a regular semantic difference between similar sentences with co więcej 'what's more' and tym bardziej 'all the more', see for example (12), where if co więcej 'what's more' is used, it makes the two pieces of information appear as adding information about who will help ('not only it will be her, but also others'), while if tym bardziej 'all the more' is used, the two pieces of information are seen as the latter being a consequence of the former ('if she'll help, others will'). As a result of the semantic dissimilarity briefly presented here the TRS for both language units can be filled up differently

(27) Nie 'lubi Karola, co więcej nie 'przyjdzie na imprezę. 'She doesn't like Karol, what's more she won't come to the party.'

(28) Nie 'lubi Karola, tym bardziej nie 'przyjdzie na imprezę. 'She doesn't like Karol, all the more she won't come to the party.'

In both sentences given above the subject for the whole utterance is the same she. But the things said about her are different. In (27) the speaker says something negative about her, something (probably) connected with what is spoken about, e.g.

(27') Nie 'lubi Karola, co więcej nie 'przyjdzie na imprezę - taka ona już jest: wiecznie stwarza problemy towarzyskie. 'She doesn't like Karol, what's more she won't come to the party - this is what she's like: always causing social problems.'

In (28) on the other hand the speaker is saying something about her that is associated with her feelings towards Karol: that she won't come to the party because she doesn't like Karol and the party is somehow connected with him.

The difference discussed here can be also observed in the following pair of sentences: 
(29) Karol zacho'rował, co więcej Jana wy'rzucą z 'pracy. 'Karol got sick, what's more John is going to be fired.'

(30) Karol zacho'rował, tym bardziej Jana wy'rzuca z 'pracy. 'Karol got sick, all the more John is going to be fired.'

The structure of both sentences is the same. However, the connection between the two parts (a cotext and a particle-sentence) occurs within a different framework, i.e. the superordinate thematic part is not the same in both cases. In (29) the superordinate theme is about something bad that has happened in the company, in (28) - about the interrelationship of Karol and Jan in the company ${ }^{8}$. It appears then clear that while analyzing contextual particles one not only has to identify the structure of linked utterances (and the nature of the bonds), but also establish a primary TRS - just as it shall be determined in conjunction-sentences. This TRS is revealed only when a particle is used (it is not de facto possible to read the TRS correctly without determining a superordinate thema, for which the nature of sub-TRS binding is a rhema). This shows that a thesis such as the one that co więcej 'what's more' "introduces an expression implying a state regarded as more important in the circumstances than what has been spoken about earlier" (Walusiak 1999: $31^{9}$; transl. - A.K.), although expressing intuition coherent with language facts, is not very useful due to insufficient specifying of TRS.

\section{W szczególności 'in particular' and the individual requirements connected with TRS}

I would like to devote the last few words to a short description of a language unit having a strong and specified expectations as regards filling up TRS - w szczególności 'in particular'. While the previously described requirements of tym bardziej 'all the more' and co więcej 'what's more' can be recognized as class requirements (i.e. being a comment to a rhema is a feature of particles by definition (as it is agreed here), while a superordinate rhema is a feature appearing in utterances with contextual language units), the requirements of $w$ szczególności 'in particular' are individual and of a semantic nature. The expectance of $w$ szczególności 'in particular' concerns fulfilling a rhema positions that can be approximated as necessity to include $R_{2}$ in $R_{1}$, see

(31) Uważam, że wszystkie egzaminy są stresujące, w szczególności te, które sprawdzają szybkość reakcji. 'I believe that all exams are stressful, in particular the ones checking reaction rate.'

The TRS of such a shape is possible also for tym bardziej 'all the more' see for example the utterance in (14) - which is often seen as synonymous to the subgroup of particles consisting inter alia $w$ szczególności 'in particular'. Is sharing

\footnotetext{
${ }^{8}$ See even more clearly in Ala jest alkoholiczka, tym bardziej nie będziemy wyciagać jutro wódki na spotkaniu. 'Ala is an alcoholic, the more we won't bring vodka to the meeting tomorrow.' ( $\mathrm{T}_{0}$ Ala i my — stosunek do alkoholu 'Ala and us — the attitude towards alcohol').

9 co więcej ,wprowadza wyrażenie implikujące stan rzeczy oceniany jako ważniejszy w danych okolicznościach niż stan rzeczy, o którym mówiono wcześniej”
} 
such features, being contextual and commenting a rhema in similarly structuralized sentences, enough to consider two language units to be synonymous? Even a cursory observation of their function and usage shows that all the suggestions on their convergence in meaning, moreover on such a convergence of the whole subgroups that they belong to, are ungrounded. The only thing these language units have in common is contextuality - a feature they share with a lot of other units, not necessarily only particles. The primary task of $w$ szczególności 'in particular' is to point to an object belonging to a certain set, an object about which knowledge is of some bearing for what is spoken about. It is worth noticing here that tym bardziej 'all the more' will not appear in the types of usage that are the most typical for the subgroup of $w$ szczególności 'in particular', see (33b)

(32a) Czyta książki, w szczególności historyczne. 'He reads books, in particular historical ones.'

(32b) ??Czyta książki, tym bardziej historyczne. 'He reads books, all the more historical ones.'

(33a) Nie czyta książek, tym bardziej historycznych. 'He doesn't read books, all the more historical ones.'

(33b) Nie czyta książek, w szczególności historycznych. 'He doesn't read books, in particular historical ones.'

Why? After all, the meaning of tym bardziej 'all the more' given earlier does not stand in contradiction with a structure of this type of sentences. However, it is not pragmatically correct to reinforce the statement 'he reads historical books' with the fact that 'he reads books'. In other words, it is not true that reading books implies reading historical books. As to (33a), the message given there seems to be a surplus, breaking the Gricean Maxim of Quantity (if one says that the person in question does not read books, it is not necessary to add that the person does not read historical books as the first statement includes the latter). Only by stressing the particle, like in

(33a') - On uwielbia książki historyczne! 'He loves historical books!'

- Nie czyta 'książek, tym "bardziej historycznych. 'He doesn't read books, all the more historical ones.',

can we achieve a correct, semantically and pragmatically understandable utterance. (33a') is a polemic sentence, discussing previously expressed opinion on someone's passion for reading ('you cannot say that he reads historical books because as he doesn't read books at all, so he can't read historical ones'). When analyzing sentences like the above ones it becomes even clearer that the link between $\mathrm{TR}_{1}$ and $\mathrm{TR}_{2}$ in the sentences with tym bardziej 'all the more' has to be specified.

It is worth mentioning here that the above stays true also for the particles in question commenting on a sentence-rhema introduced by $\dot{z} e$. In dictionaries of Polish contemporary language expressions of a shape: particle $+\dot{z} e$ (see for example 
ISJP $^{10}$ ) are erroneously considered to be conjunctions. Moreover, such expressions built with $\dot{z} e$ 'that' and particles from the two presented groups (adding particles such as tym bardziej 'all the more' and singling out particles such as $w$ szczególności 'in particular', zwłaszcza 'especially') are seen as synonymous. It is indeed true that particles in such uses are easily mutually substituted, see

(34) Ala nie zda, tym bardziej / zwłaszcza / szczególnie, że się nie uczyła. 'Ala will not pass, all the more / especially / particularly that she has not been studying.'

(35) To ciekawe, co pan pisze, tym bardziej / zwłaszcza / w szczególności że demokracja się chwieje. 'It's interesting what have written, all the more / especially / in particular that democracy is falling.'

These are de facto sentences with an omitted component, see

(35a) To ciekawe, co pan pisze, tym bardziej [biorąc pod uwagę to], że demokracja się chwieje. 'It's interesting what you're writing, all the more [considering the fact] that democracy is falling.'

(35b) To ciekawe, co pan pisze, zwłaszcza [biorąc pod uwagę to / to], że demokracja się chwieje. 'It's interesting what you're writing, especially [considering the fact / the fact] that democracy is falling.'

(35c) To ciekawe, co pan pisze, w szczególności [to], że demokracja się chwieje. 'It's interesting what you're writing, in particular [the fact] that democracy is falling.'

(34a) Ala nie zda, zwłaszcza [biorąc pod uwagę to / z tego powodu], że się nie uczyła. 'Ala will not pass, especially [considering the fact / because of the fact] that she has not been studying.'

(34b) Ala nie zda, tym bardziej [biorąc pod uwagę to / z tego powodu], że się nie uczyła. 'Ala will not pass, all the more [considering the fact / because of the fact] that she has not been studying.'

It is indeed true that these language units can substitute one another, however not without a change in meaning. For example, in (34a) the message should be read as 'it was her not studying enough which is not indifferent for knowing that she'll fail', while in (34b) as 'her not studying has reinforced my certainty that she'll fail'. All in all, it has to be stated that these two sentences are not of identical structure but have different superordinate themas, the boundary between a cotext and a particle-sentence is different, and even rhemas $\left(\mathrm{R}_{1}\right.$ for $z w t a s z c z a$ would be 'reasons she will fail to', for tym bardziej 'she will not pass') are different. As such these sentences cannot be considered as having identical meanings. It is even clearer in

\footnotetext{
$10 W$ szczególności że is not, for unknown reasons, distinguished in dictionaries although it functions similarly as other expressions of the kind. As I have proved before, none of these sequences has a status of a language unit (Kisiel 2009).
} 
(35a)-(35c), where the missing component of a sentence is not the same in every case.

A purely linguistic fact confirming the hypothesis on nonidenticality of the TRSes of the sentences with these particles is that there is a possibility of transforming (34a) to

(36) Ala nie zdała, zwłaszcza / szczególnie [z tego powodu], że się nie uczyła. 'Ala failed, especially / particularly [because of the fact] that she has not been studying.'

while blocking such a transformation of (34b), see

(37) *Ala nie zdała, tym bardziej, że się nie uczyła. 'Ala failed, all the more that she has not been studying.'

Sentences with tym bardziej 'all the more' present the speaker concluding, being convinced of something as being true, providing something else has been also true. Sentences with zwłaszcza 'especially', szczególnie 'particularly', w szczególności 'in particular', on the contrary, do not bring the information on epistemic states of the speaker. This is why the reconstruction of the sentence TRS with these language units can be done differently.

\section{Notes on contextuality in Polish dictionaries}

The cursory review presented above, of different behaviour of particles suspected to be contextual, shows how difficult it is on the one hand to examine and describe semantics of these language units, and on the other, to discover the mechanisms of hierarchization of information in a text without having the structures of the sentences with the initially described particles. Using a component 'I'm going to say more' in an explication of contextual particles, together with other quickly formulated hypotheses in linguistic literature, should be rethought as not capturing the variety of bounds between a rhema commented by a particle and a cotext. Yet, it is true that some theses given in the literature on the subject are surprisingly pertinent, for example Ewa Walusiak's thesis on contextuality being a feature close in its essence to valency (Walusiak 1999: 108 inn.).

In dictionaries of contemporary Polish language it is not common to inform on language unit contextuality. Even ISJP, which in principle reconstructs syntactic behaviour of language units within definiendum, does not present particles with their characteristic TRS arrangement. Particle contextuality is only mentioned in their definitions, where it is - not always in an explicit way - showed that a particle demands something to be said earlier. It is yet difficult to see it as a rule of presenting the properties of the elements of the class. Including contextual requirements in particle definitions seems to happen more on the basis of the entry author's intuition.

The deliberate decision on taking the feature discussed here into consideration was made for the first time while drawing up Wielki stownik języka polskiego (The Great Dictionary of Polish Language), which is being prepared by a team coordinated by the Polish Academy of Science. In this dictionary the information on 
contextuality is presented within a definition (in a regular, set way) and additionally as a label "contextual particle" in a TRS-box within a SYNTAX-block for so-called function words. The extended version of the information will appear in Stownik gniazdowy partykut polskich (The Nest Dictionary of Polish Particles), currently in preparation. In this dictionary every language unit will be presented together with an indication of its place in a TRS (analogically to a type of notation proposed for conjunctions by Jadwiga Wajszczuk), then the relation between the corresponding elements of the structure will be specified within DEFINITION- and SYNTAX-boxes. The information on filling up TRS will be given explicitly in the boxes: COMPLETIVITY and USAGE LIMITATIONS. Compared to Wielki słownik języka polskiego, the information on a language unit placement in a sentence will also be broadened, i.e. the precise data on a particle's mobility within a TRS will be given. Also, for contextual particles the information on their relocation together with a commented rhema in regard to a cotext will be given. Following these two publications it can be expected that the information on contextual requirements will be retained in Polish lexicography. Meanwhile, linguists working on metatextual language units should pay attention to possible contextual attachments, and if any of these turn out to form an inalienable feature of a language unit, it has to be described in a way that would render the nuances of a particular attachment type.

\section{References}

Grochowski, Maciej \& Kisiel, Anna \& Żabowska, Magdalena (2009). Problemy definiowania jednostek metatekstowych w stowniku. Między przyjaznościa a naukowościa, Prace Filologiczne 56, pages 145-160. (In Polish).

ISJP: Bańko, Mirosław (Ed.) (2000). Inny słownik języka polskiego. Wydawnictwo Naukowe PWN, Warszawa.

Kisiel, Anna (2009). Partykuły komentujące zdania podrzędne a granice jednostek języka: casus zwłaszcza. Zarys problematyki, In Graf, Elena \& Rabiega-Wiśniewska, Joanna \& Thielemann, Nadine (Eds.). Beiträge der Europäischen Slawistischen Linguistik (Polyslav) 12. Verlag Otto Sagner, München - Berlin, pages 53-61. (In Polish).

Kisiel, Anna (in press). Preliminary remarks on particles' contextuality. Erroneous thoughts on submerging particles in context, Studies in Polish Linguistics.

PSWP: Zgółkowa, Halina (Ed.) (1994-2005). Praktyczny słownik wspótczesnej polszczyzny, Kurpisz, Poznań.

SWJP: Dunaj, Bogusław (Ed.) (1999). Słownik wspótczesnego języka polskiego, Wilga, Warszawa.

SJPDor: Doroszewski, Witold (Ed.) (1958-1969). Słownik języka polskiego, PWN, Warszawa.

USJP: Dubisz, Stanisław (Ed.) (2003). Uniwersalny słownik języka polskiego, Wydawnictwo Naukowe PWN, Warszawa.

Wajszczuk, Jadwiga (1997). System znaczeń w obszarze spójników polskich. Wprowadzenie do opisu, Katedra Lingwistyki Formalnej UW, Warszawa. (In Polish).

Walusiak, Ewa (1999). Hierarchizacja treści i nawiazanie wewnatrztekstowe. Wykładniki leksykalne, Energia, Warszawa. (In Polish). 